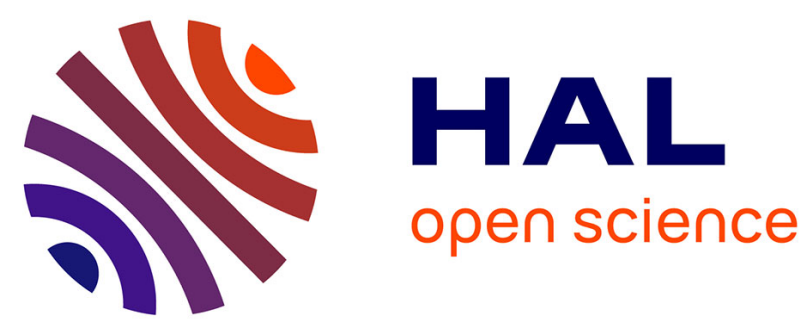

\title{
THE MULTI OBSERVATIONS THEMATIC ASSEMBLY CENTRE OF THE COPERNICUS MARINE ENVIRONMENT MONITORING SERVICE
}

Stéphanie Guinehut, B Buongiorno Nardelli, T Chau, F Chevallier, D Ciani, Hervé Claustre, H Etienne, M Gehlen, E Greiner, S Jousset, et al.

\section{To cite this version:}

Stéphanie Guinehut, B Buongiorno Nardelli, T Chau, F Chevallier, D Ciani, et al.. THE MULTI OBSERVATIONS THEMATIC ASSEMBLY CENTRE OF THE COPERNICUS MARINE ENVIRONMENT MONITORING SERVICE. 9th EuroGOOS International conference, Shom; Ifremer; EuroGOOS AISBL, May 2021, Brest, France. pp.284-291. hal-03335202v2

\section{HAL Id: hal-03335202 \\ https://hal.science/hal-03335202v2}

Submitted on 24 Sep 2021

HAL is a multi-disciplinary open access archive for the deposit and dissemination of scientific research documents, whether they are published or not. The documents may come from teaching and research institutions in France or abroad, or from public or private research centers.
L'archive ouverte pluridisciplinaire HAL, est destinée au dépôt et à la diffusion de documents scientifiques de niveau recherche, publiés ou non, émanant des établissements d'enseignement et de recherche français ou étrangers, des laboratoires publics ou privés. 


\section{THE MULTI OBSERVATIONS THEMATIC ASSEMBLY CENTRE OF THE COPERNICUS MARINE ENVIRONMENT MONITORING SERVICE}

Stéphanie Guinehut (1), B. Buongiorno Nardelli (2), T. Chau (3), F. Chevallier (3), D. Ciani ${ }^{(4)}$, H. Claustre ${ }^{(5)}$, H. Etienne ${ }^{(1)}$, M. Gehlen ${ }^{(3)}$, E. Greiner ${ }^{(1)}$, S. Jousset ${ }^{(1)}$, S. Mulet ${ }^{(1)}$, R. Sauzède ${ }^{(5}$ and N. Verbrugge ${ }^{(1)}$

(1) Collecte Localisation Satellites, Environment and Climate, Ramonville Saint-Agne, France, sguinehut@groupcls.com

(2) Consiglio Nazionale delle la Ricerche, Istituto di Scienze Marine, Naples, Italy

(3) Laboratoire des Sciences du Climat et de l'Environnement, Institut Pierre-Simon Laplace, CEA-CNRS-UVSQ, Gif sur Yvette Cedex, France

(4) Consiglio Nazionale delle la Ricerche, Istituto di Scienze Marine, Rome, Italy

(5) Laboratoire d'Océanographie de Villefranche, Institut de la Mer de Villefranche, CNRS-INSU, Sorbonne Université, Villefranche-Sur-Mer, France

\section{Abstract}

Complementary to ocean state estimates provided by modelling/assimilation systems, a multi observations-based approach is available through the MULTI OBSERVATIONS (MULTIOBS) Thematic Assembly Center (TAC) of the European Copernicus Marine Environment Monitoring Service (CMEMS). CMEMS MULTIOBS TAC provides multiobservation-based ocean products at global scale derived from the combination of two or more different sensors from satellite and in situ, and using state-of-the-art data fusion techniques. These products cover the blue ocean for physics and the green ocean for the carbonate system and biogeochemical variables. MULTIOBS products are available in Near-Real-Time (NRT) or as Multi-Year Products (MYP) for the past 25 to 35 years with regular temporal extensions. MULTIOBS TAC provides also associated Ocean Monitoring Indicators (OMIs). It uses mostly inputs from other CMEMS TACs.

Keywords: in situ, satellite, multi observations, data fusion techniques, CMEMS 


\section{Introduction}

MULTIOBS TAC products are available through CMEMS catalogue (https://marine. copernicus.eu/). They consist of global ocean state-estimates of variables still currently critically under-sampled at most of the major scales, take advantage of the strength of the Global Ocean Observing System (in situ and satellite), stay close to the observations, resolve mesoscale structures at the right place (when eddy permitting) and provide long, stable time series enhancing ocean climate and ocean health monitoring capabilities. MULTIOBS TAC delivers 4 physical, 1 carbon and 2 biogeochemical products and 3 associated OMls which are first described. Some perspectives are then listed below.

\section{MULTIOBS TAC products}

\section{$2.1 \mathrm{SSS} / \mathrm{SSD}$}

CNR produces a global 2D sea surface salinity (SSS) and sea surface density (SSD) L4 product by interpolating in situ SSS and SSD data with the multidimensional OI technique originally introduced by Buongiorno Nardelli (2012). This method is able to extract information on the surface patterns from satellite Sea Surface Temperature (SST) L4 data, increasing the effective resolution of the interpolated fields. The technique, originally developed to interpolate SSS, has been modified by Droghei et al. (2016) to provide dynamically consistent SSD field. It has been further modified to ingest satellite fields from SMOS. The product is provided on a $1 / 4^{\circ}$ regular grid at weekly sampling (monthly averaged fields are also available) from 1993 onward (MULTIOBS_GLO_PHY_S_SURFACE_MYNRT_015_013).

\subsection{ARMOR3D}

ARMOR3D which is developed by CLS provides on a $1 / 4^{\circ}$ horizontal grid at weekly sampling (monthly averaged fields are also available) 3D global fields of temperature, salinity, geopotential heights and geostrophic currents down to the bottom on 50 vertical levels and 2D global fields of mixed layer depth. This L4 product is available as a multi-year time series since 1993 and in near-real time (MULTIOBS_GLO_PHY_ TSUV_3D_MYNRT_015_012). It is obtained by combining satellite (sea level anomaly (SLA), geostrophic currents, SST and SSS) and in situ (T/S profiles) observations through statistical methods (multiple linear regression, optimal interpolation, thermal wind equation: Guinehut et al., 2012; Mulet et al., 2012).

ARMOR3D is used together with 4 global reanalyses (GREP) and the in situ gridded field CORA (COriolis Re-Analysis) to monitor global ocean warming through a specific Ocean Monitoring Indicator for the Global Cumulative Trend of zonal mean Subsurface Temperature. Estimation of the robustness of the indicator is provided from a multiproduct approach. From ARMOR3D solution, confirmed by all solutions, the warming is obvious in almost all part of the ocean and at depths of up to $800 \mathrm{~m}$ depth (Figure 1). 


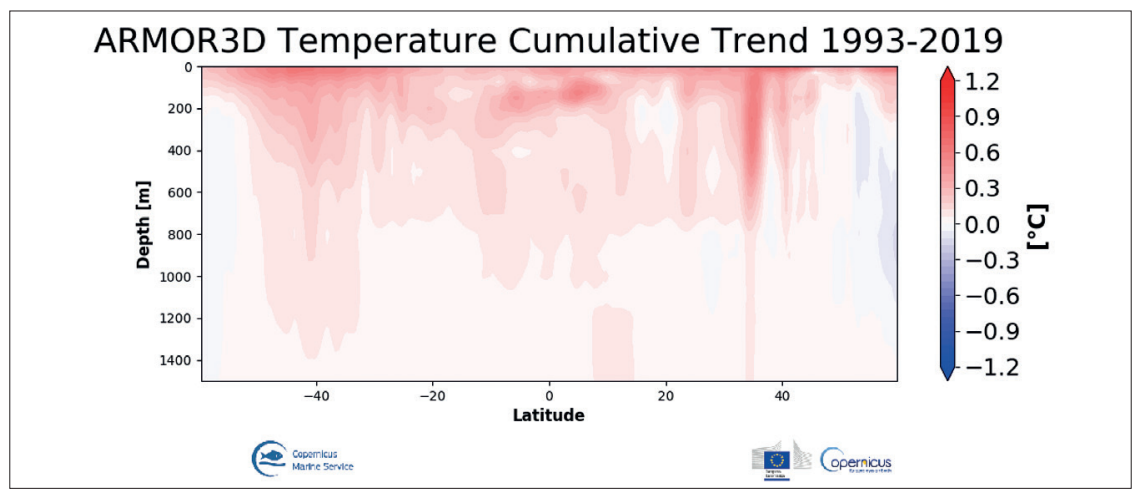

Fig. 1. ARMOR3D Depth/Latitude global mean temperature cumulative trend over 1993-2019 (in ${ }^{\circ} \mathrm{C}$ ).

\subsection{OMEGA3D}

A new multiyear product called OMEGA3D (MULTIOBS_GLO_PHY_W_3D_ REP_015_007) and developed by CNR provides observation-based 3D quasigeostrophic vertical and horizontal ocean currents over 75 levels from the surface to $1500 \mathrm{~m}$ depth, at $1 / 4^{\circ}$ horizontal resolution, for the period January 1993 to December 2018. The current velocities are obtained by solving a Q-vector formulation of the Omega equation, including diabatic forcing terms (Buongiorno Nardelli, 2020). This product is based on the combination of the fields of temperature, salinity and geostrophic currents provided by ARMOR3D and ERA-Interim surface fluxes.

\subsection{Copernicus-Globcurrent Surface and near-surface current}

Although it is well recognized that surface currents in the ocean are not the simple addition of different current components, a simple approximation of ocean currents can be made by adding the geostrophic currents derived from the altimeter Absolute Dynamic Topography fields and an estimate of the Ekman response to wind forcing. Based on the work by Rio et al., (2014), CLS produces total velocity fields (zonal and meridional) at $0 \mathrm{~m}$ and $15 \mathrm{~m}$ depth and at $6 \mathrm{~h}$ frequency in near-real time (MULTIOBS GLO_PHY_NRT_015_003) and at $3 \mathrm{~h}$ frequency for the multi-year time series (MULTIOBS_GLO_PHY_REP_015_004). Daily and monthly means are also available. The multi-year time series currently covers the 1993-May 2020 period and is extended in the near-real time.

The geostrophic currents are calculated through the geostrophic approximation applied to the sum of altimeter SLA and a mean dynamic topography (MDT), both coming from CMEMS Sea Level TAC. The Ekman currents are computed at two depths $(0 \mathrm{~m}$ and $15 \mathrm{~m}$ ) applying an empirical Ekman model updated from Rio et al., (2014) to ECMWF wind stress fields. The parameters of the empirical Ekman model are 
computed using in situ observations from Argo drifts at the surface, SVP-type drifters at $15 \mathrm{~m}$ and an estimation of the ocean stratification coming from the mixed-layer depth of ARMOR3D.

\subsection{CMEMS-FFNN Surface Carbon}

The surface carbon multiyear product includes air-sea flux of $\mathrm{CO}_{2}\left(\mathrm{fgCO}_{2}\right)$, partial pressure of $\mathrm{CO}_{2}\left(\mathrm{spco}_{2}\right)$ and pH (MULTIOBS_GLO_BIO_CARBON_SURFACE_REP_015_008). The model called CMEMS-FFNN is inherited from the EU H2O2O AtlantOS project and is developed by LSCE. It relies on the implementation of feed-forward neural network models (FFNN) for the interpolation of sparse carbon system measurements to basinwide maps on a $1^{\circ}$ horizontal resolution grid at a monthly period (Denvil-Sommer et al., 2019). This method establishes non-linear relationships between chosen drivers or 'predictors' such as SST, SSS, chlorophyll, mixed layer depth, surface height, $\mathrm{pCO}_{2}$ climatology, and the target, here surface ocean $\mathrm{pCO}_{2}$ measurements from SOCAT (https://www.socat.info/). Reconstructed variables $\left(\mathrm{fgco}_{2}, \mathrm{spco}_{2}, \mathrm{pH}\right)$ are distributed with associated uncertainties derived from the 100-member CMEMS-FFNN ensemble. Related OMls for ocean carbon sink (i.e. global yearly integrated air-sea flux of $\mathrm{CO}_{2}$ ) and ocean acidification (i.e. global mean sea water $\mathrm{pH}$ ) are also available. CMEMSFFNN air-sea $\mathrm{CO}_{2}$ flux product contributes since 2019 to the yearly assessment of the Global Carbon Budget (Friedlingstein et al., 2020).

\subsection{CANYON Nutrient profiles}

The so-called method CANYON-B (CArbonate system and Nutrients concentration from hYdrological properties and Oxygen using a Neural-network) is inherited from the EU H2020 AtlantOS project and R.Sauzède PHD thesis and is developed by LOV/IMEV. It relies on a neural-network method to derive, from 'simple' and costeffective measured parameters from Biogeochemical-Argo (BGC-Argo) profiling floats, some more complex biogeochemical measurements, not yet easily or costeffectively amenable to robotic detection (Sauzède et al., 2017; Bittig et al., 2018). CANYON-B uses measurements of temperature, salinity, pressure, and oxygen together with sampling latitude, longitude, and date to retrieve the concentrations of three nutrients including nitrates $\left(\mathrm{NO}_{3}{ }^{-}\right)$, phosphates, $\left(\mathrm{PO}_{4}{ }^{3-}\right)$ and silicates $\left(\mathrm{Si}(\mathrm{OH})_{4}\right)$. It has been trained on high quality nutrient data collected over the last 30 years and made available through the GLODAPv2 database. It is then applied to all available delayed-mode qualified BGC-Argo profiling floats equipped with an oxygen sensor. Nearly 100000 profiles are currently available in CANYON product (MULTIOBS_GLO_ BIO_NUTRIENTS_PROFILES_REP_015_009).

The example along Argo float WMO 6901467 trajectory located in the North Western Mediterranean Sea shows winter mixing in the input fields (temperature, salinity, oxygen) in February/March 2013 and associated uplift of reconstructed nutrients (Figure 2). 


\subsection{SOCA3D POC/b $/ \mathrm{bp} / \mathrm{Chla}$}

The SOCA3D biogeochemical multiyear product provides global gridded fields of Particulate Organic Carbon (POC), backscattering coefficient $\left(\mathrm{b}_{\mathrm{bp}}\right)$ and Chlorophyll-a concentration (Chla) at depth (MULTIOBS_GLO_BIO_BGC_3D_REP_015_010), three biogeochemical variables still currently critically under sampled at all scales. The method relies first on a neural network method called SOCA (Satellite Ocean-Color merged with Argo) which is inherited from the EU H2O2O AtlantOS project and R.Sauzède PHD thesis. SOCA estimates vertical profiles of backscattering coefficient $\left(b_{b p}\right)$, a biooptical proxy for POC, from surface ocean color satellite measurement of bbp and additional physical drivers (Sauzède et al., 2016). It has been trained on high quality $b_{b p}$ data collected from BGC-Argo floats. Then, an empirical parameterization is used to infer the vertical distribution of Chla from surface ocean color satellite observations of Chla and the relative position of the mixed layer and euphotic depths (Uitz et al., 2006). This parameterization was established from a database of $\mathrm{Chl}$ profiles acquired by High Performance Liquid Chromatography (HPLC), the reference method for such measurements. Both methods are developed at LOV/IMEV. The multiyear product is available on a $1 / 4^{\circ}$ horizontal grid over 36 vertical levels from the surface to $1000 \mathrm{~m}$ depth, at a weekly time period and for the $1998-2019$ period. An associated monthly mean climatology is also available.

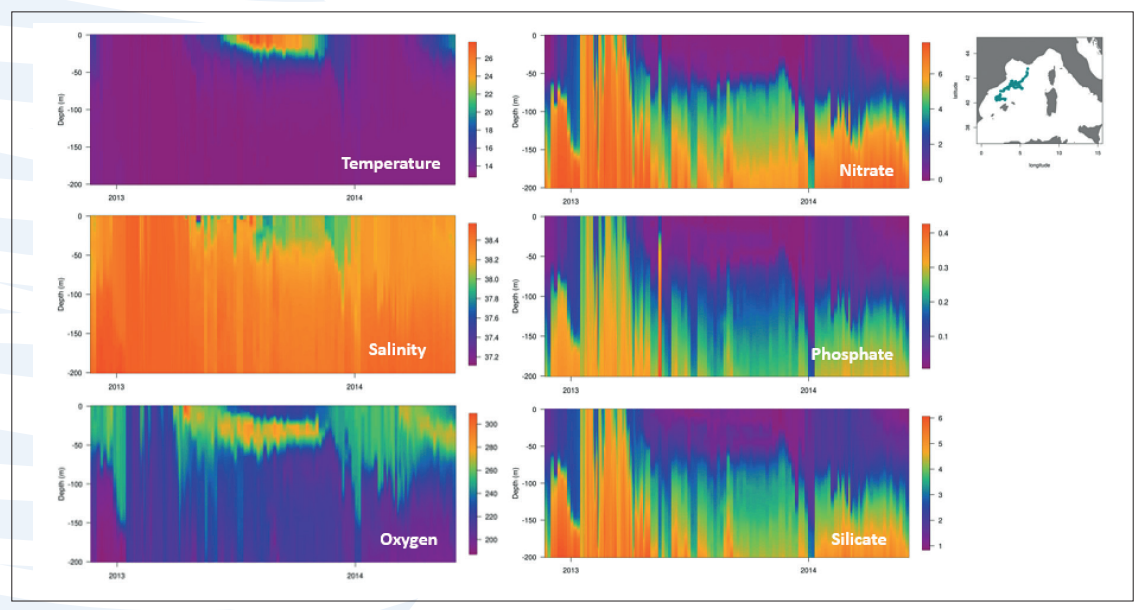

Fig. 2. Depth/Time Temperature (in ${ }^{\circ} \mathrm{C}$ ), Salinity (in psu) and Oxygen (in $\mu \mathrm{mol} \mathrm{kg}^{1}$ ) measurements from Argo float WMO 6901467 located in the North Western Mediterranean Sea and associated Nitrate, Phosphate and Silicate (in $\mu \mathrm{mol} \mathrm{kg}^{1}$ ) profiles as reconstructed by CANYON-MED (Fourrier et al., 2020). 


\subsection{Quality assessment}

All products are fully validated applying a methodology defined and agreed with CMEMS, inheriting the long experience of MyOcen and MERSEA series of projects (Hernandez et al., 2018). A dedicated QUID (QUality Information Document) is associated with each product/OMI and is available through the generic address: https://resources.marine.copernicus.eu/documents/QUID/CMEMS-MOB-QUID-015$X X X$.pdf (XXX to be replaced by the number of the product).

\section{Perspectives}

Perspectives include to remain at the state-of-the art in terms of methods and upstream data for which continuous monitoring is performed. New/improved products from CMEMS TACs (Sea Level, SST, Ocean Color, Wind, in situ) will be incorporated and tested as well as products currently outside of CMEMS, such as SSS from Aquarius/ SMAP and from the future ESA-CIMR (Copernicus Imaging Microwave Radiometer) mission. Perspectives include also the improvement of the information content of the products by increasing resolution in space (horizontal \& vertical) and in time for all MULTIOBS products, starting with the physical ones. Higher resolution (L3/L4) products from CMEMS TACs are thus required. OMEGA3D, nutrient profiles and 3D POC/ Chla products currently available only as multi-year time series could be extended to the near-real-time, providing fully consistent multi-year and near-real time series for almost all MULTIOBS products. The representation of physical processes such as ageostrophic component (wind-driven, stokes), higher frequency processes (e.g. tides) as well as mesoscale processes (e.g. vertical extension of eddies) will be improved. New variables such as phytoplankton functional types, total primary production, or vertical profiles of carbonate chemistry (alkalinity, pH, DIC) will be added. Derived quantities such as Ocean Heat Content (ECV) could be easily provided. Efforts will be made to provide uncertainties estimate for all variables for both direct use, validation purposes and data assimilation.

\section{Acknowledgements}

This work has been funded by the European 'Copernicus Marine Environment Monitoring Service' under contract 83-CMEMS-TAC-MOB. 


\section{References}

Bittig, H. C., Steinhoff, T., Claustre, H., Fiedler, B., Williams, N. L., Sauzède, R., Körtzinger, A. and Gattuso, J.-P., 2018: An Alternative to Static Climatologies: Robust Estimation of Open Ocean CO2 Variables and Nutrient Concentrations From T, S, and $\mathrm{O} 2$ Data Using Bayesian Neural Networks. Frontiers in Marine Science, 5, 328, doi:10.3389/fmars.2018.00328.

Buongiorno Nardelli, B., 2012: A Novel Approach for the High-Resolution Interpolation of In situ Sea Surface Salinity. Journal of Atmospheric and Oceanic Technology, 29, 867-879, doi:10.1175/JTECH-D-11-00099.1.

Buongiorno Nardelli, B., 2020: A Multi-Year Timeseries of Observation-Based 3D Horizontal and Vertical Quasi-Geostrophic Global Ocean Currents. Earth System Science Data, N. 12, 1711-1723. https://doi.org/10.5194/essd-12-1711-2020.

Denvil-Sommer, A., Gehlen, M., Vrac, M., and Mejia, C., 2019: LSCE-FFNN-v1: a twostep neural network model for the reconstruction of surface ocean $\mathrm{pCO}_{2}$ over the global ocean. Geosci. Model Dev. 12, 2091-2105. doi: 10.5194/gmd-12-2091-2019.

Droghei, R., B. Buongiorno Nardelli, and R. Santoleri, 2016: Combining in situ and satellite observations to retrieve salinity and density at the ocean surface. Journal of Atmospheric and Oceanic Technology, doi:10.1175/JTECH-D-15-0194.1.

Fourrier, M., L. Coppola, H. Claustre, F. D'Ortenzio, R. Sauzède and J.-P. Gattuso, 2020: A regional neural network approach to estimate water-column nutrient concentrations and carbonate system variables in the Mediterranean Sea: CANYON-MED. Frontiers in Marine Science, https://doi.org/10.3389/fmars.2020.00620.

Friedlingstein P., M. O'Sullivan, M. W. Jones, R. M. Andrew, J. Hauck, A. Olsen, G. P. Peters, W. Peters, J. Pongratz, S. Sitch, C. Le Quéré, J. G. Canadell, P. Ciais, R. B. Jackson, S. Alin, L. E. O. C. Aragão, A. Arneth, V. Arora, N. R. Bates, M. Becker, A. Benoit-Cattin, H. C. Bittig, L. Bopp, S. Bultan, N. Chandra, F. Chevallier, L. P. Chini, W. Evans, L. Florentie, P. M. Forster, T. Gasser, M. Gehlen, D. Gilfillan, T. Gkritzalis, L. Gregor, N. Gruber, I. Harris, K. Hartung, V. Haverd, R. A. Houghton, T. Ilyina, A. K. Jain, E. Joetzjer, K. Kadono, E. Kato, V. Kitidis, J. Ivar Korsbakken, P. Landschützer, N. Lefèvre, A. Lenton, S. Lienert, Z. Liu, D. Lombardozzi, G. Marland, N. Metzl, D. R. Munro, J. E. M. S. Nabel, S-I. Nakaoka, Y. Niwa, K. O’Brien, T. Ono, P. I. Palmer, D. Pierrot, B. Poulter, L. Resplandy, E. Robertson, C. Rödenbeck, J. Schwinger, R. Séférian, I. Skjelvan, A. J. P. Smith, A. J. Sutton, T. Tanhua, P. P. Tans, H. Tian, B. Tilbrook, G. van der Werf, N. Vuichard, A. L. P. Walker, R. Wanninkhof, A. J. Watson, D. Willis, A. J. Wiltshire, W. Yuan, X. Yue, and S. Zaehle, 2020 : Global Carbon Budget 2020. Earth System Science Data, 12, 3269-3340, DOI: 10.5194/essd-12-3269-2020.

Guinehut S., A.-L. Dhomps, G. Larnicol and P.-Y. Le Traon, 2012: High resolution 3D temperature and salinity fields derived from in situ and satellite observations. Ocean Science, 8, 845-857, doi:10.5194/os-8-845-2012 
Hernandez, F., G. Smith, K. Baetens, G. Cossarini, I. Garcia-Hermosa, M. Drévillon, J. Maksymczuk, A. Melet, C. Régnier and K. von Schuckmann, 2018: Measuring performances, skill and accuracy in operational oceanography: New challenges and approaches. In 'New Frontiers in Operational Oceanography', E. Chassignet, A. Pascual, J. Tintoré, and J. Verron, Eds. GODAE OceanView, 759-796, doi:10.17125/ gov2018.ch29.

Mulet, S., M.-H. Rio, A. Mignot, S. Guinehut and R. Morrow, 2012: A new estimate of the global 3D geostrophic ocean circulation based on satellite data and in situ measurements. Deep-Sea Research II, 77-80, 70-81, doi:10.1016/j.dsr2.2012.04.012.

Rio M.-H., S. Mulet and N. Picot, 2014: Beyond GOCE for the ocean circulation estimate: Synergetic use of altimetry, gravimetry, and in situ data proceeds new insight into geostrophic and Ekman currents. Geophysical Research Letter, 41, doi :10.1002/2014GL061773.

Sauzède, R., Bittig, H. C., Claustre, H., de Fommervault, O. P., Gattuso, J.-P., Legendre, L. and Johnson, K. S.: Estimates of water-column nutrient concentrations and carbonate system parameters in the global ocean, 2017: A novel approach based on neural networks. Frontiers in Marine Science, 4(128), doi:10.3389/fmars.2017.00128.

Sauzède, R., Claustre, H., Uitz, J., Jamet, C., Dall'Olmo, G., D'Ortenzio, F., Gentili, B., Poteau, A. and Schmechtig, C., 2016: A neural network-based method for merging ocean color and Argo data to extend surface bio-optical properties to depth: Retrieval of the particulate backscattering coefficient. Journal of Geophysical Research Ocean, 121(4), 2552-2571, doi:10.1002/2015JC011408.

Uitz, J., Claustre, H., Morel, A. and Hooker, S. B., 2006: Vertical distribution of phytoplankton communities in open ocean: An assessment based on surface chlorophyll, Journal of Geophysical Research Ocean, 111(C8), C08005, doi:10.1029/2005JC003207. 